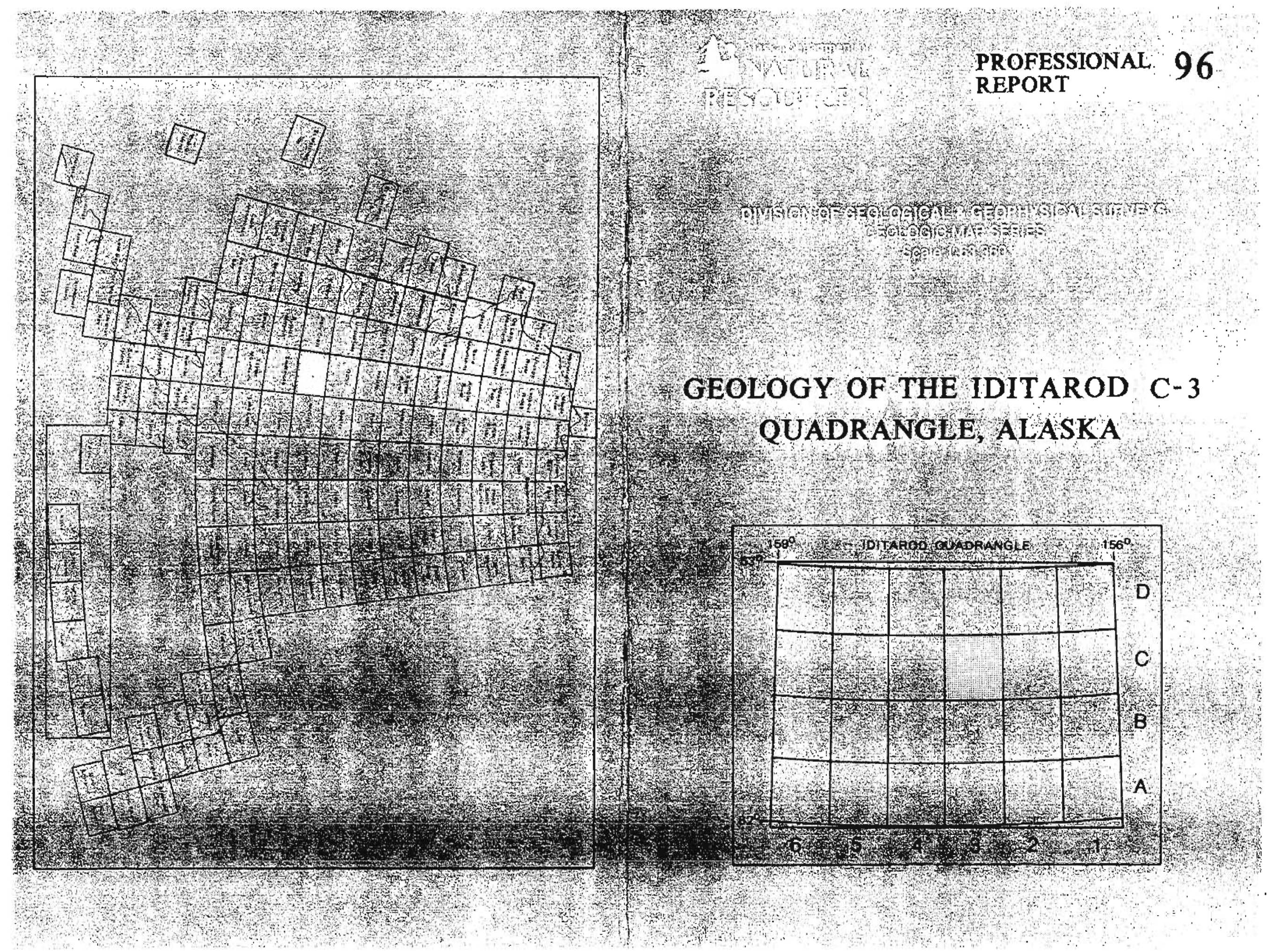




\section{GEOLOGY OF THE IDITAROD C-3 QUADRANGLE, ALASKA}

By T.K. Bundtzen, G.M. Laird, and M.S. Lockwood

PROFESSIONAL REPORT 96

A summary of the geology and mineral resources along a $32 \mathrm{~km}$ (20 mi) segment of the Nixon-Iditarod fault in the central

Kushokwim Mountains of western Alaska

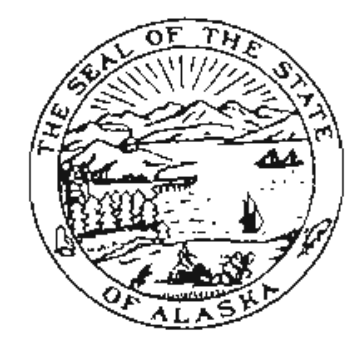




\section{INTRODUCTION AND ACKNOWLEDGMENTS}

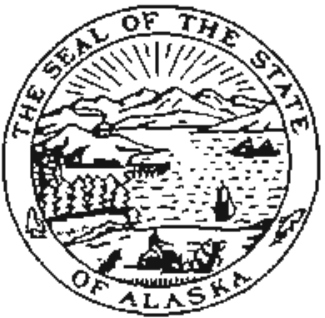

STATE OF ALASKA

Steve Cowper, Governor

\section{DEPARTMENT OF NATURAL RESOURCES} Judith M. Brady, Commissioner

DIVISION OF GEOLOGICAL \& GEOPHYSICAL SURVEYS Robert B. Forbes, Director and Stale Ceologist

Division of Geological \& Geophysical Surveys publications are available at the follow ing locations:

\section{Airport Way}

Fairbanks, Alaska 99709

400 Willoughby Avenue

(3rotor)

Juneau, Alaska 99801

U.S. Geological Survey

Public tnformation office

7010 Street.

Anchorage, Alaska 99513

Information Specialisi

U.S. Geological Survey

4230 University Drive, Room 101

Anchorage, Alaska 99508

Mail orders should be addressed to the Fairbanks office. Cost $\$ 7.50$.
The Iditarod (-3 Quadrangle lies on the eastern coge of the Kuskokwim Mountains, a maturely dissected upland of accordant, rounded ridges and

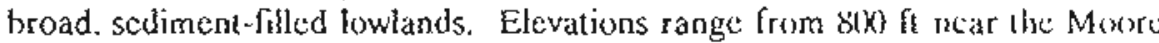
Creck gold mine 103,009 f a VABM Willow. The results presented here are a continuation of mapping completed to the northeast by Bundlien and Laird (1982, 1983a, 1983b). This map is prepared in copperalion with the $U$. 5

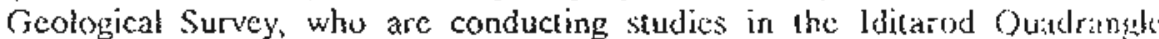
under the Alastat Mineral Resource Assessment Progran.

We lhank Dun Harris of McGrah for discussions of the Mone Crock trold placers, the Broken Shovel silver-gold deposit, and the gencrat mining history of the map area; and J.T. Kline (DGGS) for spending suveral days with the ficld party during 1983 iavestigations. We apprciate the support of $1 \mathrm{k} !$ Bltm (formcrly with DGGS), who provided potassium-argon radionel ric itges (map shect, lable 2); Jim Barker (U.S. Bureau of Mines), who providud benelication studies of the chrome placers (map sheet, table 3); and M.K. Folly.

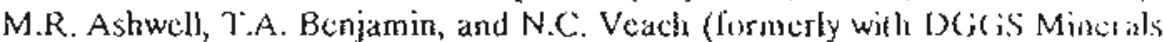
Laboratory), who provided limely geochemical and major-oxide analyses (man sheet, tables 1 and 5). Last, we would like to acknowledge Kline and Mami 1 . Miller (U.S. Geological survey) for their thought ful reviews of the mantescript.

\section{BEDROCK GEOLOGX}

The ofdest unit in the map area is a thin strucfural sliver of radiolarian chert and luflaceous sindstone (JPzc) near Deatwood Creck corrulative with rocks of the Palcocoic through Jurassic lnnoko terrate to the northeast (Chapman and others, 1982; Bundtzen and Laird, 1983a). Major stratigrapbic units in the map arca are poorly exposed sandstone, shale, and silstone whe Kuskokwim Group (Cady and others, 1955), tanging in agc liom late E.ırly io Latc Cretaceous. In the study area, lwo different sections ol the Kuxketwim Group are juxtaposed along the Nixon-ldiarod lault. Southeas of the laull, the section is composed of tolded undiferentiatcd turbidites and shallow-matrine and nonmarioe clastic deposits, totaljng at least $3,500-\mathrm{m}$ thick; the seytence is not subdivided because of a lack of adequate bedrock conlrol. Northwest of the Nixon-Iditarod fault, the Kuskokwim Group is 2,700)-m thick and can be subdivided inlo mappable unis. The northwesterly sequence is very simitar to the stratigraphic scelion described by Bundeen and Laird (1983a) $60 \mathrm{~km}$ wo tho 
northeast (map sheet, correlation diagram). All the Cretaceous units interfinger laterally and vertically.

The oldest recognized Cretaceous unit (Ksh) in the area consists of shale, siltstone, and fine-grained lithic sandstone deposited as turbidites in a lower- to mid-fan environment. Distinctive calcareous turbidites (Kslt and $\mathrm{Ks}$ ), rich in plaot fragments and Inoceramus shell fragments, overlie the fine-grained clastic turbidites (Ksh). Higher in the section are increasing amounts of volcaniclastic sandstonc (Ksv) and flora-rich, pebble-bearing, medilum- to coarse-grained lithic and sublithic saadstone (Ksc). These units (Ksv and Ksc) probably represent a coarse (perhaps inner) turbiditefan dcpositional environnent because of the presence of Bouma Tabc cycles (Bouma, 1962), sand-to-shale ratios that cxcecd 5:1, charnclized sandstone bodics, and numerous thute custs.

Near the top of the section are relatively clean quartzose sindstone and plant-debris-rich shaie of the Kssq unit. Lithologic characteristics, the absence of turbidity-current indicators, and the well-laminated nature of the quartz-rich sands suggest that this clastic sequence was deposited in a narginat- to shatlowmarine (or nonmarine) environment, possibly neat a storm-dominated(?) shoreline (Sharma and others, 1972). Similar units to the northeast and southwest contain leaf beds and thin, discontinuous coal seanss (Mertic, 1936; Patton and others, 1976; Bundtzen and Gilber, 1983).

Sparce paleocurrent data from high-energy flow-regime structures in the iurbiditc units (Ksle, $\mathrm{Ks}$, and $\mathrm{Ksc}$ ) suggest southwesterly or westcrly current direcions; however, paleocurrent direclions from low-energy how-rcgime indicators in the Kssq tenit are dominantly northeasterly (table 6).

Overlying the Cretaceous clastic rocks is a 300 - 10500 -m-tbick package of subaerial wolcanic rocks that is part of a $400-\mathrm{kna}^{2}$ volcanic freld best exposed in the Beaver Mountains to the north (Bundtzen and Laird, 1982). The volcanic pile cau be subdivided into five mappable trits that range from rhyolite to basalt but predominate in porpbyritic to nonporphyritic pyroxene andesire. The basal unit (Kvt), composed of altered andesite and dacite, contains interbedded sublithic sandstone and shale identica! to lithologies in the undcrlying lithic to sublithic sandstone unit Ks. This relationship suggests conformigy between the underlying Kuskokwim Group and the overlying volcanic rocks. The basal unit (Kvt) is successively overlain by intermediate volcanic rocks (Kvi), porphyritic andesite (TKvip), volcanic agglomerate (TKva), and mafic volcanic rocks (TKvm)-mainly olivine-augite basalt.

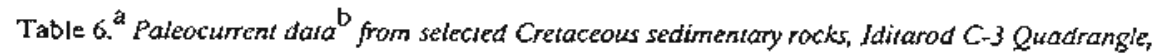
southwesiem Alacka

\begin{tabular}{|c|c|c|c|c|}
\hline $\begin{array}{c}\text { Map } \\
\text { no. }\end{array}$ & $\begin{array}{l}\text { Field } \\
\text { no- }\end{array}$ & $\begin{array}{l}\text { Azimuth } \\
\text { cortocted for tilt } \\
\text { (degrees) }\end{array}$ & $\begin{array}{c}\text { Grand } \\
\text { mean } \\
\text { (degrees) }\end{array}$ & $\begin{array}{l}\text { Fow } \\
\text { regime }\end{array}$ \\
\hline \multirow[t]{4}{*}{1} & 8313T16 & 10 & 18.7 & Inrwei \\
\hline & & 20 & & \\
\hline & & 15 & & \\
\hline & & 30 & & \\
\hline \multirow[t]{3}{*}{2} & $838 \mathrm{Br} 11$ & 70 & 50.6 & lower \\
\hline & & 68 & & \\
\hline & & 14 & & \\
\hline \multirow[t]{2}{*}{3} & 33BT18 & 240 & $237 \mathrm{~s}$ & Upper \\
\hline & & 235 & & \\
\hline \multirow[t]{4}{*}{4} & $8312 T 86$ & I 60 & 144.2 & Upper \\
\hline & & 145 & & \\
\hline & & 162 & & \\
\hline & & 110 & & \\
\hline \multirow[t]{5}{*}{5} & $83 B 787$ & 230 & 241 & Uppir \\
\hline & & 225 & & \\
\hline & & 245 & & \\
\hline & & 240 & & \\
\hline & & 265 & & \\
\hline \multirow[t]{4}{*}{6} & 8315161 & 210 & 200.5 & $U_{\Gamma \Gamma r}$ \\
\hline & & 200 & & \\
\hline & & 204 & & \\
\hline & & 188 & & \\
\hline
\end{tabular}

\footnotetext{
Sce map shect for tables $1-5$.

Measurced by ' $\mathrm{l}$ K. Bundizen on striations, groowe casts, flow casts, and cross-beds.
}

Southcast of the Nixon-Iditarod fauk, an enigmatic unit of algglomeralc, cherl, and breccialcd wolcanics (Kac) crops out from Moore Crcek northcast to the head of Shoaty Creck. The stratigraphic position of the volcanic unit is uncertain; hence, it is unclear whether the unit is equivalent to the Late Cretaceous to casly Terliary Beaver Mountains volcanics or to ofder volcanics interbedded will the Kuskokwim Group. 
Four small (2-10 4-km² monzonite to quartz moszonite plutons intrude the wolcanic rocks near Maybe, Willow, and Moore Creeks, and a fifth pluton intrudes the Crelaceous section on the south flank of Cameiback Mountain. Hornfels aureoles extend about $0.5 \mathrm{~km}$ from the contact zones of the plutons. The three sorthernmost plutons are crudely aligned in a $12-\mathrm{km}$-long, northtrending zone that extends from the Nixon-Iditarod fault at Moore Creek to Moose Creek, suggesting emplacement along a cross-fracture system.

Results of major-oxide analyses and ClPW normative mineralogy for igneous rocks in the map area (map sheet, table 5) are similar to results previously publisbed for igneous rocks to the north (Moll and others, 1981; Bundizen and Laird, 1982, 1983a, 1983b). Andesite, rhyolitc, and quartz monzonite show broad calc-alkatine trends; monzonitic stacks and plutons are subalkaline and silica saturated. Basalt and basaltic andesite have higher than average aikali content and usualy contain both normative and modal olivine and occasionally normative nepheline. Corundum-normative dacite to alaskite domes or sills intrude the Nixon-Yditarod and Moore Creek fault zones both within and north of the map area. Bundtzen and Swanson (1984) suggested that, overall, the suite is alkali-calcic and represents a transition from calcalkaline to alkaline rocks.

Potassium-argon dares obtained from biotite, hornblende, plagioclase, and whole-rock samples in the map area ranged from 58 to 71 m.y. (map sheet, table 2), typical of ages reported from coeval volcanic and plutonic units in the Medfra (Moll and others, 1981) and Innoko-Takotna areas (Bundtzen and Laird, 1982, 1983a).

\section{OUATERNARY GEOLOGY}

Quaternary deposits were subdivided by photogeology and ground reconnaissance. Most of the study area was not glaciated during Pleistocene time; howewer, the 2,700- to 3,000-ft uplands at the beadwaters of Montana Creek on Camelback Mountain and of Maybe and Moore Creeks north of Camelback Mountain were probably occupied by at least three small valley glaciers. Modified cirque morphology suggests correlation with the early Wisconsin Bifurcation Creek glaciation in the nearby Beaver Mourtains (Bundtzen, 1981).
Tertiary through Quaternary uplift along the Nixon-Iditarod fauth accelerated erosion of old pediment surfaces and terrace altwium. On Fourth of July and Willow Crceks, cxlcosive aprons of alluvium and colluvium were deposifed where streams emerged from upland source areas. Evolution of a fan-terrace complex ( $\mathrm{OCl})$ aliong the trace of the Nixon-Idiarod lath may hive important signilicance for concentration of heavy-minerd placers near Moro Crcek. Widespread deposiss of organic silt are presently accumulating (rer lowland areas; bowewer, thermokarst processes are modifying these and ot her Outernary deposits in the study areat.

\section{STRUCTURAL GEOLOGY}

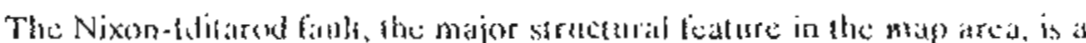
high-angle, Isanseurrent faut that juxtaposed the volcanic and selimenury rocks to the rorilhwest agaiust the turbidite-dominated clastic depasits to ale solutheass. Bawen 65 and 69 mallion years ago, bodies of thyolite Here

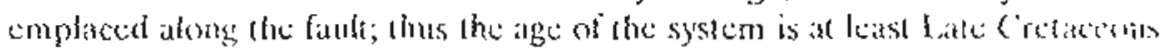

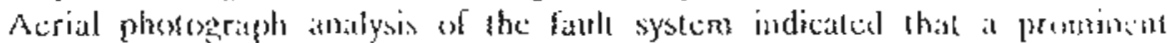

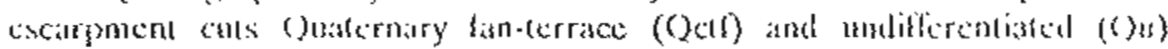

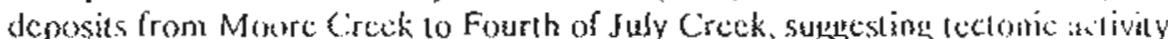
in Pleistocenc---possibly botocene-nime. Acriaj photograph interpictation

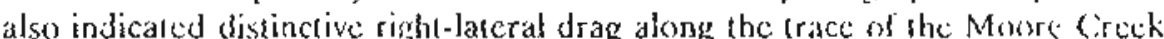
fauk, which is evidenced by defermed bedding ncar Banner Circk.

Vokeanic ind sedinentary rocks northwest of the Nixon-1 Jitarod fatslt have been folded into brad, northeast-trending syrchines and anticlines with

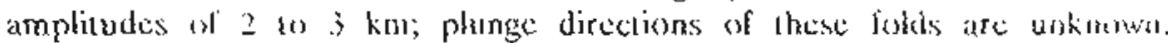
Exicnsive Ouaternary cover grevented detailed fold analysis sutheis of the Nixor.Iditarod finslt; however, structurat rends and bodding intitudes deermined firm acrial pholographs suggest significan compressional stress directed at the wedge-shupied block belween the Moore Croek and Nixoniditarod fauks.

Columnar jointing in some outcrops of the andesite (TKva) and basalt (TKvm) units indicaies that volcanic flows werc deposited in a subacrial environmed that postdatco masine deposition of the Kuskokwim Group. 


\section{ECONOMIC GEOLOGY}

Mineral deposits of economic significance in the area include the goldcinnabar-chromite placer deposits on Moore, Fourth of July, and Deadwood Creeks, the Brokent Showel silver-gold lode, and sand-and-gravel deposils in tailings along Moore Creek. Gcochemical results of a reconnaissance chipsampling program are reported in table 1 (see map sheet); samples are from ferricrete gossan in volcanic and plutonic rocks, mineral prospects, and fauh zones. We emphasize that most of the sampling was neither uniform nor represcntative; however, chip-chandel samples collected at the Broken Shovel lode are believed to be fairly representative of parts of the mincralized system. The sampling effor revealed sublie mercury, silver, and lead anomalies in the gossan zones of the altered andesite and dacitc unit (Kv). Pcrvasive alteration in the unil may be wholly stratigraphic in origin or may have been thermasly induced by emplacement of the plutons on Maybe and Willow Crecks.

The Broken Shovcl lode (map sheet, geologic sketch and (able 1, site 33) is a tetrahedrite-arsenopyrite-quartz-tourmaline vein \pm scheelite, hosted in a shear zone of altered monzonite of the Moore Creek pluton. It was discovered and cxplored by Warner Stewart of Flat, Alaska, sometime prior to World War If and rcmained dormant until 1981 when the deposit was crosscut by two large exploration frenches. The viti is 1- to 4-m thick, dips steeply to the southeast, and has sharp contacts will the enclosing monzonite. Although obscured by vegetation and colluvium at both ends, is can be traced along strike for at least $100 \mathrm{~m}$. The mineralized win includes 5- to 10-percent total sulfides. Arscnopyritc is commonly attered to scorodite, and tetrahedrite grains are gencralfy surrouaded by malachitc stains. Fluid-inclusion bomogenization temperatures from quartz in the shear zone range from $25410380^{\circ} \mathrm{C}$ and average $297^{\circ} \mathrm{C}(\mathrm{N}=14)$. In mincralogy, structural style, and melat content, the vejn is similar to the Cirque and Tolstoi deposits $45 \mathrm{~km}$ north (Bundizen and Laird, 1982) and to the Golden Horn deposit at Flat, $60 \mathrm{~km}$ to the southwest (Bundlzen and Gibert, 1983). All of these deposits contain copper, silver, gold, tungstea, and minor bismuth or tin and are localized in recently unroofed cupolas of differentiated, sub-alkatine plutons or stocks that intrude the Cretaceous clastic section (Bundtzen and Swanson, 1984).

A $300-\mathrm{m}^{2}$ area of agate and distinctive green to light-blue chalcedony veins culs altercd volcanic rocks (Kv1) near the head of Moose Creck (map sheet, table 1 , sites 10,11 and 13 ). The veins vary from $2-1020-\mathrm{cm}$ wide but cannot be traced along strike because much of the material is contained in frost-riven rubble. Samples of the agate and blue chalcedony have been polished in tumblers and form handsome stones suilable for show or jowelry. (Addilional agate localities are indicated on the map.)

Anomalous copper, lead, ziac, and silver occur in faull breccias and contact zones in hornfels near the Camelback Motntain pluton (map shcet, table 1, siles 35, 37, and 38). No placer-gold concentrations, however, atc known downstrcam of these mineralized arcas.

Virtally at smineral production in the study area has been derived froma gold placers on Moore Crcek (map sheet, placer-site 4). These placers, and those on Nevada (islch, were initially hand mined in 1913, constitueing the lirst gold discoveries in this subunil of the Idtarod mining distria. During the twenties, thielies, and fortics, Finnish immigrants Utilla and Kutur mined the lower benches and modern stream alluvium on Moore Creek for a distance of nearly $2 \mathrm{kn}$. About $20,000 \mathrm{oz}(622,000 \mathrm{~g})$ of placer goll were recowered, miainly from 1935 to 1943. During the fiftics and sixties, Joe and Jutes Stuver mined bench gravels ncar the modern-day gold camp on Moore Creck.

Total mincrat produclion from Moorc Creck is estimaled at 54,000 wh $(1,679,400 \mathrm{~g})$ of gold and $12,500 \mathrm{oz}(388,750 \mathrm{~g})$ of silver based on examination of unpublished U.S. Mint relurns through 1968 and discussions with Don Harris. current owner of the claims. Gold fincess averages 758 with silver and copper as major impuritics. Gold size is generally coarse; in recent years, nuggels have ranged to $19 \mathrm{or}(591 \mathrm{~g})$.

The Moore Creck placers occur in terrace, fan-terrace, and modern strearn alluvium that varies from 1- to 5-m thick and averages about 2-m thick. Rounded streani-gravel clasts average $30-\mathrm{cm}$ diam and consist of augite basalt ( 60 percent), silicilicd sandstone (20 pereent), monzonite (10 perena), and minor shalc (10) pereent); heavy minerals include magnctite, chromite, and zircon, minos cinnabar, and traces of scheelite, native silver, and totrahedritc. The bedrock surface of the paystreak is Cretaceous shale and sandstone, containing local iron-rich concretions to $20-\mathrm{cm}$ diam (map shect, table 1 , site 34).

The source of the Moore Crcek placers is probably the deeply dissccicd monzonite plug that crops out on the hillside $2.5 \mathrm{~km}$ northwest of Moore Creek 
placer camp. The monzonite plug hosts numerous crosscutting, mineralized sulfide-quartz veins, including the Broken Shovel silver-gold lode previousiy described. During earlier years, the modern streams draining the monzonite were mined for placer gold.

The Nixon-Iditarod fault forms the southern structural boundary of the Moorc Creck pluton and has experienced right-lateral strike-slip movement of up $1090 \mathrm{~km}$ since Cretaceous time (Granc, 1966; Patton and others, 1984). Wc speculalc that through Tertiary and Quaternary lime the placer deposits were offset from their lode serurec by the ighe-lateral faule movement so that the despesits become prengressively yeunger to the noriheast. Therelore, older, undinewered bench placers may occur farther to the southwest (1e:XI, lig. l)

Pluer gold was discovered and developed on Fourth of July Creck (map shect, pitcer-sitc 3) in 1915 (Donald Harris, oral commun., 1984). Recent cxploration athd developenent aelivity coninues. No past preductien figures are available, but Roberl and Manxie Magnoson of McGrath recowercd modest amounts of gold during the 1982-83 fich seasons. Two mine-concentratc samples from the creek, andiyred by lte DGGS Mincrals falloratory, yiclded Fincness valoues of 853 and 899 .

The fourth of July Creck deposits appear to be contained entircly in Holucence alluvium that consists of rounded clasts of basalt, hornfets, and monjonite $101-\mathrm{m}$ diam. The large size of the boulders has presented a rccowery preblem during placer-mining activities. In addition to frec gold, heavy-mineral concentrales in the creek include chromite, cinnabar, frce mercury, and potybasite. Bedrock consists of decomposed andesitc and tuff of the KW unit, which is probably a poor catchment sutface for plucer gold. The frescent placer cut is in at high-cnergy part of the strean wilh hydrologic gradients $10250 \mathrm{~m} / \mathrm{km}$. Buter prosneclive pay could possibly be found 2 to $3 \mathrm{~km}$ lethw the grescent uperation at the canyon breakout, where the bedrock surface is Cretaceous clastic rock and the hydrologic gradient is more maturc, averaging $80 \mathrm{~m} / \mathrm{km}$. The probable source of gold in Fourth of July Creek is at the soulhern conlact of Maybe Creek pluton. At the northern contact of the pluton on Maybe Creck (placcr-sitc 2), pan-concentrate samples from our sudies have revealed consistent gold anomalies.

During the 1984 mining season, Don Harris began developing a large, shallow, low-grade placer-gold deposit near the head of Deadwood Creek (map

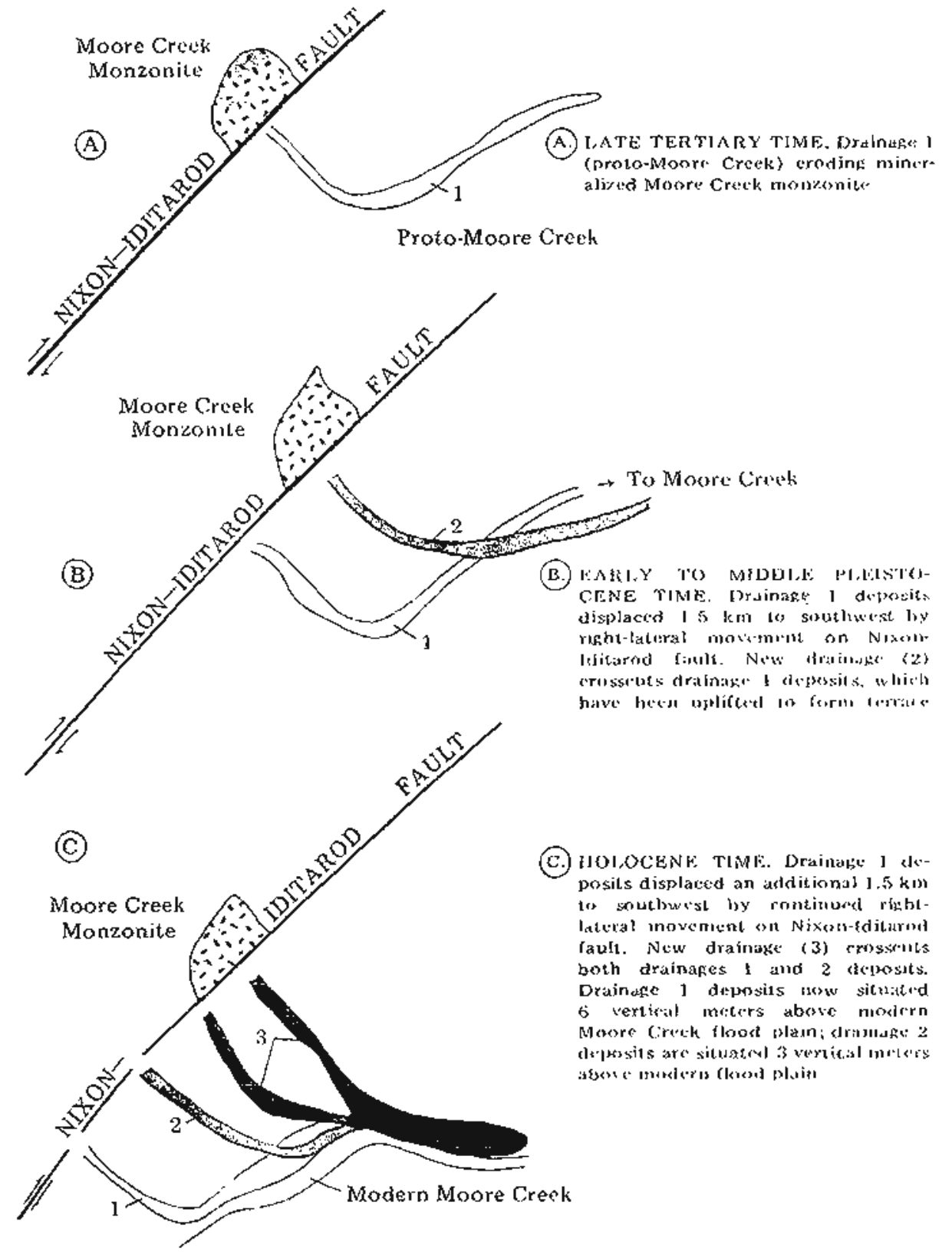

Figurc 1. Spcenlalive cvolution of Moore Creck placer diposits, Iditarol C-3 Quadrangle, southwestern Alaska, showing successive displacement of drainages by right-latcral movenent along the Nixon-Ictitisod fatult. 
sheet, placer-site 1). According to Tovio Rosander (oral commun., 1983), the deposit was discovered in the late 1930s and consists of fine gold in shallow gravels 2- to 3-rn thick with 1 to $3 \mathrm{~m}$ of muck overburden. The source of the gold may be a former stream (now captured) that drained the mineralized Maybe Creek pluton to the east.

Benefication studies of low-grade chromite placers at Moore and Fourth of July Creeks are summarized in table 3 (see map sheet). Table concentrations of 0.23 percent chromium were obtained at Moore Creck and 2.08 -percent chromiurs al Fourth of July Creek. Both values are too Inw to be conomically significant.

Sand-and-gravei deposits are widespread in terrace-alluvium, fan-terrace, and modern hood-plain dcposits. At least 2 million tons of high-quality, washcd-and-stacked aggregatc exist in the placer tailings of Moore creck.

\section{REFERENCES CITED}

Bouma, A.H., 1962, Sedimentology of some flysch deposits: Amsterdam, Elsevier, $168 \mathrm{p}$

Bendtzen, T.K., 1981, Mutliple glaciation in the Beaver Mountains, western interior Alaska: Alaska Division of Geological and Geophysical Surveys Geologic Report 63, p. 11-18.

Bundizen, T.K., and Gibert, W.G., 1983, Oulline of geofogy and mineral resuurces of upper Kuskokwin region, Alaska, in Recd, K.M., ed. Proceedings of the 1982 Symposium on Western Alaska Cicology and Resource Potential: Anchorage, Alaska Geological Socicty, v. 3, p. 101119 .

Bundizen, T.K., and Laird, G.M., 1982, Geologic map of the lditarod D.2 and casicrn D-3 Quadrangles, Alaska: Alaska Division of Gonlogical and (ivorhysicat Surveys Professional Repor 72, scale 1:63,360, l shect.

Bundizen, T.K., and Laird, G.M., 1983a, Geologic map of the lditarod D-1 Quadrangle, Alaska: Alaska Division of Geological and Gcophysical Sirveys Professional Report 78, scale 1:63,360, 1 sheet.

Bundizen, T.K., and Laird, G.M., 1983b, Geologic map of the McGrath D-6 Quadrangle, Alaska: Alaska Division of Geological and Geophysical Survcys Professional Repor 79, scalc 1:63,360, 1 sheet.
Bundtzen, T.K., and Swanson, S.A., 1984, Geology and petrology of igneous rocks in Innoko River area, western Alaska [abs.): Geological Society of America Cordilleran Section, Abstract with Programs, v. 16, no. 5, p. 273.

Cady, WM., Wallace, R.E., Hoare, J.M., and Webber, E.J., 1955, The central Kuskokwin region, Alaska: U.S. Gcological Survey Prolessional Paper $268,132 ?$.

Chapman, R.M., Pátın, W.W., Jr., and Moll, E.J., 1982, Preliminary summary of geology of eastern Ophir Quadrangle, in Coonrad, W.I..., ed., The United States Geological Survey in Alaska: Accomplishments during 1980) U.S. Geolsgical Survey Circular 844, p. 70-73.

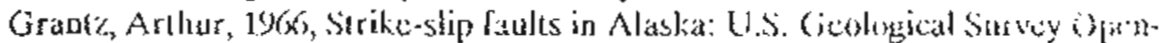
file Report $66,53,82 \mathrm{p}$, scale $1: 63,360,4$ sheets.

Hollick, Arthur, 19.30, The Upper Cretaceous thoras of Alaska: U.S. Geolingical Survey Prolessional Paper 159, $123 \mathrm{p}$.

Meric, J.B., 19\$, Mincral denosits of the Ruby-Kuskokwim region, Aiskat: U.S. Cicolugical Survey Bulletin $864-C$, p. 115-247.

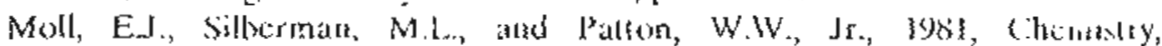
mineralogy, and $K-A r$ ages of igneous and metamorphic rocks of Medfra Quadrangle, Alaska: U.S. Geological Survey Opren-file Rcpor $80 \mathrm{S17C}$, $19 \mathrm{p}$.

Patton, W.W., Jr., Disto, J.T., Jr., and Chapman, R.M., I976, Leitc P'atcornic and Mesocoic strarigraphy af the Nixon Fork area, Medfra Qhadrangic, in Blean, K.M., ed., The United States (icolngical Sumcy in Aloski: Accomplishaneris during 1976; U.S. Genlogical Survey Circular 751-B, p. B.38.B4h.

Patton, W.W, Ji., Moll, E.J., and King, H.H., ISW, The Altikinn mineral resource atsessment prograni: Guide to infurmation contained in the folio of geolobic and mineral resource mans af the Mcoftra Guadragli, Naska: U.S. Goological Survey Circular $928,11 \mathrm{p}$.

Sharna, G.D. Nuidu, A.s. and Hood, D.W., 1972, bristul Bay: Model contemporary graded sheil: Americin Associatiosh of Petroleum Geclogists Bulfutin, v. 56, nu. $10,2.2000-2012$ 